\title{
Die blywende noodsaaklikheid van die beoefening van die Algemene Kerkgeskiedenis*
}

JJ STEENKAMP

\section{INLEIDING}

Met die begrip "Algemene Kerkgeskiedenis" word dié geskiedenis van die kerk aangedui wat buite Suid-Afrika verloop het. Dit geld ter onderskeiding van die geskiedenis van die kerk in Suid-Afrika (Kyk Jaarboek 1982, Universiteit van Pretoria. Deel VI, bl 9). Die vraag wat beantwoord moet word, is waarom dit in Suid-Afrika blywend noodsaaklik is om die Algemene Kerkgeskiedenis te beoefen. Hierdie vraag het veral verskerp sedert die rampspoedige Cottesloe-beraad in 1960 en word opnuut gestel ná die vergadering van die World Alliance of Reformed Churches te Ottawa in Augustus 1982. Om sinvol daarop te antwoord, is dit noodsaaklik om na enkele beskouings oor die kerkgeskiedenis te gaan kyk, soos dit sedert die dae van Eusebius van Caesarea ontwikkel het. Uiteraard kan dit hier slegs oorsigtelik gedoen word.

\section{ENKELE BESKOUINGS OOR DIE KERKGESKIEDENIS SEDERT EUSEBIUS VAN CAESAREA}

\subsection{Eusebius van Caesarea (264/5-337/341)}

Eusebius was bewus daarvan dat hy die eerste geskiedskrywer van die kerk was. Daarom val dit op dat hy maar 'n kort motivering gee van waarom hy die werk onderneem. Sy eie beskouing oor die werk word gedeeltelik duidelik wanneer hy verwys na persone wat voor hom brokstukkies van gebeurtenisse wat hulleself beleef het, opgeteken het. Hy sê daarvan (kyk Kraft 1967):

"Ihre Stimmen erheben sie wie ferne Feuerzeichen; irgendwo aus der Vorzeit rufen sie wie von ferner Warte uns zu und geben uns Weisung, wie wir zu gehen und den Gang der Erzählung sicher und gefahrlos zu lenken haben" (H.E. I, 3).

Dit blyk dat 'n mens moet aanvaar, dat Eusebius sy eie werk ook in dié lig beskou het.

- Referaat gelewer by die Kongres van die Kerkhistoriese Genootskap, November 1982. 
Van grondliggende betekenis (vgl. Pont sa c:39) vir die kerkgeskiedenis is die feit dat hy sy werk begin by die optrede van Christus en eindig met 'n messiaanse hooglied oor die oorwinning van Konstantyn oor Licinius in 324 n.C. Hieruit kan besluit word dat daar reeds in hierdie vroeë dae van die kerkgeskiedenis, juis danksy die Christendom ' $n$ liniêre geskiedsbeeld geheers het in teenstelling met die sikliese van die Grieke (Berkhof 1966:16; kyk ook Dreyer 1974:224). Dreyer toon aan dat deur middel van die Joods-Christelike godsdiens, vir die eerste keer wêreldgeskiedenis in die werklike sin van die woord na vore tree. Dit was sekerlik die verdienste van Eusebius dat hy hiertoe 'n bydrae gelewer het (Meinhold 1967:95).

Eusebius het 'n stempel op die kerkgeskiedenis geplaas wat dwarsdeur die Middeleeue tot in die Hervorming sy nawerking gehad het, deurdat hy die geskiedenis beskryf het as die gevegsterrein van die goddelike waarheid teen die magte van Satan (Meinhold 1967: 96). By hierdie geskiedsbeeld het Augustinus aangesluit.

\subsection{Aurelius Augustinus (354-430)}

Augustinus word beskryf as die eintlike Christelike geskiedenisfilosoof. Berkhof stel dat sy hoofwerk, De Civitate Dei, tot vandag toe die klassieke boek van die Christelike geskiedenisopvatting gebly het (Berkhof 1966:20). Wat sekerlik behartenswaardig is, is dat Augustinus die eerste persoon was wat sin in die geskiedenis ontdek het. Dit was geleë in die worsteling tussen die aardse en die ewige ryk. Die aardse ryk gaan tot niet in 'n ydele kringloop, maar die koninkryk van God gaan deur stryd heen, die ewige heerlikheid tegemoet (Berkhof 1966:20). Augustinus bring met sy liniêre visie van die geskiedenis, (wat die werk van God in die geskiedenis is) wat uitloop op die voleinding, baie duidelik sin in die kerkgeskiedenis. Die vroeëre wederkomsverwagting van die oergemeente wat nie dadelik vervul word nie, lei nou nie tot resignasie nie. Daarenteen word deur die bepaling van ' $n$ eindpunt in die geskiedenis die eschaton en die telos aangedui waarsonder daar geen sin in die geskiedenis kan wees nie (Dreyer 1974:221).

\subsection{Die Kerkhervorming}

Nadat die Middeleeue geen noemenswaardige kerkgeskiedskrywing voortgebring het nie (Pont s a c:39), maak die hervormers erns daarmee. Tereg stel Emmen (1944:96):

"Hervormers zijn niet zoozeer

menschen, die geschiedenis schrijven

en beoordelen als wel maken en wenden." 
Die hervormers se beskouings oor die kerkgeskiedenis en geskiedenis überhaupt is verspreid te vinde in hulle geskrifte. Luther sê die taak van die kerkgeskiedenis is om die geskiedenis van die ware kerk te beskrywe. Melanchton beskou die geskiedenis as onderwysen opvoedingsmiddel van die mens, maar ook as middel om God se werk mee te leer ken. Calvyn meen dat die hele geskiedenis deur God bepaal word, dat (soos die ander Hervormers ook) die geskiedenis die worstelstryd van die koninkryk van God is teen die bose magte soos wat dit ook by Eusebius en Augustinus na vore kom (Pont s a c:50).

Die hervormers gaan van die standpunt uit dat die geskiedenis twee oriënteringspunte het, naamlik die sondeval en die voleinding. Hiertussen vorm die koms van Christus die middelpunt van die geskiedenis (Berkhof 1966:20). Daarom werk hulle sterk met die kerk-idee (Emmen 1944:112). Hierdeur trek die hervormers die mens in in die stryd van die koninkryk van God teen die bose magte met sterk klem op die verantwoordelikheid van die mens in die stryd. Hy moet sy verantwoordelikheid voor God dra. Daarom is kerkgeskiedenis vir die hervormers nooit geskiedenis op sigself nie, maar alles wat geskied, sien hulle in die lig van God, coram Deo (Emmen 1944:120).

\subsection{Die rasionalisme}

Met die opkoms van die rasionalisme van die begin van die $17 \mathrm{de}$ eeu af, het ' $n$ radikale verandering in die geskiedsbeeld na vore getree. Dit hang saam met die verwerping van die openbaring ten gunste van die ratio. Waar die gesag van die openbaring nie meer aanvaar word nie, is dit logies dat die kerk, wat uit die openbaring voortgekom het, ook met nuwe oë bekyk word. In hierdie tyd het die ortodoksie die fout begaan om die kerkgeskiedenis bloot te gebruik as ' $n$ arsenaal waaruit geput kan word om die polemiek en die apologetiek teenoor die rasionalisme te voer (Meinhold 1967:419). Op dié manier kon daar uiteraard niks teregkom van die ware strydpunt naamlik openbaring en ratio nie. Dit is seer sekerlik die probleem van enige ensiklopediese tydperk in die geskiedenis van die kerk.

Algaande dus, begin die kerkgeskiedenis sy reformatoriese stempel verloor, deurdat die kerkgeskiedenis irrelevant raak met betrekking tot die probleme wat die rasionalisme opwerp. Dit lei uiteindelik daartoe dat aan die een kant 'n volledige verlies van historisiteit na vore tree en aan die ander kant 'n interpretasie aan die geskiedenis van die kerk gegee word waardeur die kerk sy character sui generis verloor.

Die volledige verlies van historisiteit tree in werking by John 
Locke, en die deïste. Hoewel Locke nie die bestaan van openbaring ontken nie, het hy geen nut daarvoor nie. Wat vir die mens nodig is om te weet, kan uit die wette van die natuur afgelei word; dit duur net langer as by die openbaring.

Die god van die deiste maak dit onmoontlik om enige waarde aan die geskiedenis van die kerk te heg. As hy die wêreld soos 'n horlosie aan die gang gesit het en homself aan die afloop daarvan onttrek het, kan daar geen plek vir die kerkgeskiedenis meer wees nie. Die deïsme het juis vanweë hierdie gebrek aan historisiteit tot niet gegaan (Cragg 1970:162). Die kerkgeskiedenis sou waarskynlik indertyd daarop kon gewys het, dat die mens se geskiedenis 'n verhaal van 'n gebroke wêreld is, waarin die sonde die optimisme van die deïsme alle bestaansreg ontneem.

Aan die ander kant van die rasionalistiese spektrum tree JL von Mosheim (1693-1755) na vore. Hy fundeer die kerkgeskiedskrywing van die Aufklarüng sodat dit kan ontkom aan die nutteloosheid van die deïsme. Von Mosheim beskou die kerk as 'n sosiologiese grootheid. Hierdie grootheid is onderworpe aan die veranderinge wat in die wêreld plaasvind. Die kerkgeskiedskrywing moet die kerk soos hy verander só beskryf, dat daaruit 'n bepaalde nuttigheid vir die gemeenskap gewin kan word. Die nuttigheid van die kerkgeskiedskrywing is dus daarin geleë dat dit eendersyds die motiewe vir die verandering openbaar en andersyds tot ' $n$ verdieping van die selfkennis van die mens voer (Meinhold 1967:11).

Van die kerkbegrip van die vroeëre kerk, asook van die reformatoriese geskiedsbeskouing het kennelik niks oorgebly nie.

Lessing is die volgende persoon wat na vore kom met sy geskrif: Erziehung des Menschengeschelchts (1780). In hierdie geskrif stel Lessing dat die geskiedenis nie die worsteling van die goeie teen die kwaad is nie. Die worsteling vind nie meer plaas nie, maar daar vind eerder ' $n$ ontwikkeling plaas. Die dryfkrag van die geskiedenis is nie meer die teenstrydige kragte van God en die bose nie, maar die goeie eienskappe wat God in die mens geplaas het (Berkhoff 1966:21). Deur hierdie beskouing word die uitsonderlikheid van die kerk negeer. Dit bring egter 'n nuwe belangstelling in die kerkgeskiedenis wat bygedra het tot die optimisme van die negentiende eeu (Cragg 1970:250).

\subsection{Die negentiende eeu}

Die verskillende opwekkingsbewegings aan die begin van die negentiende eeu het ' $n$ kortstondige teruggryp na die geskiedsbeeld van die hervorming veroorsaak. Daarmee word die geskiedsbeeld van die Augklärung oorwin. In Duitsland het die romantiek groot invloed uitgeoefen om ' $n$ hernude belangstelling in die geskiedenis 
te kweek. Veral twee name kan genoem word, naamlik JG Herder en FDE Schleiermacher. Vir Herder is die geskiedenis God se werk en as sodanig 'n lewendige kommentaar op God se Woord. Die taak van die kerkgeskiedenis is nie om feitekennis bloot weer te gee nie, maar om die betekenis van historiese feite te interpreteer. Hierdie interpretasie moet egter objektief geskied (Meinhold 1967:113 v; kyk ook Smits 1944:152 vv).

Schleiermacher verbind die kerkgeskiedenis met die regering van die kerk. Sonder kennis van die kerk se verlede kan diegene wat die kerk moet regeer, nie hulle taak uitvoer nie. Die huidige tyd moet ook as 'n stuk geskiedenis beskou word. Die kerkgeskiedenis het daarom die taak om die hele geskiedenis so oor te dra, dat dit op die huidige tyd uitloop. Wesenlik is die kerkgeskiedenis die voortgaande realisering van die lewensbeginsel wat van Christus uitgaan. Die doel is die voortgaande kersteniing van die wêreld (Meinhold 1967:135).

Algaande het 'n verdere verandering ingetree. Die ratio van die Augklärung maak plek vir die ontledende verstand. Daar word nou gesoek na objektiewe bewysbare waarhede. Dit is 'n oorgang van idealistiese na empiriese en realistiese denke (Rasker 1974:113). Mede onder invloed van die empiriese natuurwetenskappe volg nou ' $n$ tyd waarin gelet word op die historiese bewysbare in die geskiedenis. Hierdie benadering in die kerkgeskiedenis staan bekend as die historisme. 'n Uitvloeisel hiervan is die radikale oortuigings van Franz Overbeck. Overbeck meen dat die kerk oftewel die Christendom reeds sedert die dae van Paulus 'n geskiedkundige grootheid geword het, omdat die kerk die wêreldlikheid van die heidendom aanvaar het. Die kerkgeskiedenis het probeer om hierdie sekularisasie te regverdig. Daarom kan die kerkgeskiedenis net een resultaat hê, naamlik om ateïsme te lei, dit wil sê die ontkenning van God (Meinhold 1967:248 v).

Adolf von Harnack staan aan die begin van die moderne kerkgeskiedskrywing. Vir hom is daar net een rede om die geskiedenis te bestudeer. Die geskiedenis moet die kennis van die teenwoordige tyd dien. Aangesien die mens van die teenwoordige tyd kousaal aan die verlede verbonde is, dien die geskiedenis daartoe om hom op te skerp tot verantwoordelike optrede. So word die mens ontruk aan die beeld van ' $n$ passiewe objek van historiese ontwikkeling. Hy word ' $n$ handelende mens wat in verantwoordelikheid teenoor die verlede en die toekoms ingryp in die gang van die geskiedenis. Die eintlike geskiedenis van die Christelike geloof en die kerk word vergestalt in die opvoedings- en geestesgeskiedenis van die Christelike godsdiens. Dit wat in 'n institusionele vorm daaruit na vore tree, is die manifestasie van die regering van die Gees in die geskiedenis (Meinhold 1967:263 vv). 
By Von Harnack kom daar dus 'n nuwe aspek in die geskiedskrywing na vore, naamlik dat die kerkgeskiedenis nie net sin het deurdat daar ' $n$ eindpunt (telos) is waarheen die kerk op pad is nie, maar dat die geskiedenis as bruikbare norm ook aangewend kan word om die handelinge van die kerk mee te bepaal.

“Die Deutung der Vergangenheit geschieht unter steter Bezugnahme auf ihren Wert für die Gegenwart und als Norm für die Zukunft" (Meinhold 1967:265).

\subsection{Die twintigste eeu}

Karl Barth het groot indruk gemaak met sy stelling dat kerkgeskiedenis ' $n$ onontbeerlike hulpwetenskap is vir die dogmatiek, eksegetiese vakke en praktiese teologie. Hy baseer sy stelling daarop dat die kerkgeskiedenis geen selfstandige vraag met betrekking tot die Christelike spreke oor God beantwoord nie. Daarmee ontsê hy aan die kerkgeskiedenis die bestaansreg as selfstandige teologiese vak (Barth 1947:3).

Barth moes egter toegee dat die saak van die kerk van die verlede, dieselfde is as dié van die hede, naamlik die verkondiging van die Woord van God. Verder moet die kerkgeskiedkundige self met die Woord van God vertroud wees om die korrektheid van die verkondiging van die kerk in die verlede te kan beoordeel (Meinhold 1967:403).

Verskillende skrywers se werk word gekenmerk deur die keuse vir of téén Barth se stelling. Ondertussen het Barth self 'n definisie van geskiedenis gegee wat die deur ooplaat vir die erkenning van kerkgeskiedenis as volwaardige teologiese vak:

"Geschiehte erkennen wir nur wenn und indem uns geschieht, vielleicht auch gegen uns geschieht, nur wenn und indem uns ein Geschehen angeht, so angeht, dass wir dabei sind, dass wir an ihm beteiligt sind" (Barth 1947:iv).

In hierdie sin word die kerkgeskiedenis 'n gesprek met die verlede wat nie sonder teologiese voorkennis gevoer kan word nie. Dit word ook 'n gesprek met die verlede wat nie negeer of ontvlug kan word nie. Solank as wat die kerk besig is om die evangelie te verkondig, sal hy noukeurig moet nagaan wat die lidmate gesê het wat hom voorafgegaan het, want dit is deur die eeue heen nog steeds dieselfde kerk.

\section{WAT IS GESKIEDENIS EN SPESIFIEK KERKGESKIEDENIS?}

Uit die voorgaande historiese oorsig het dit duidelik geword dat die 
mens en die kerk in verskillende tye verskillend oor die geskiedenis gedink het. Dit geld ook die kerkgeskiedenis. Daar is egter enkele sake wat algemeen aanvaar word.

Dit is eerstens noodsaaklik om te onderskei tussen geskiedenis en historie. Historie is die beskrywing van gebeurtenisse in die hede of die verlede soos wat dit plaasvind of plaasgevind het. Dit het wel met die mens te doen, maar het nie 'n verband met mense of gebeure wat voorafgaande, gelyktydig of daarna geleef of gebeur het nie.

Daarenteen kom geskiedenis slegs tot stand wanneer ' $n$ bepaalde historiese gebeurtenis verband hou met mense en dinge wat voorafgaande of navolgend aan die bepaalde gebeurtenis bestaan of gebeur het. Dit beteken dat geskiedenis dus slegs bestaan solank as wat daar mense is wat bepaalde gebeurtenisse uit die verlede in 'n sinvolle verband met hulle eie lewe beskou. Geskiedenis word gemaak wanneer 'n gebeurtenis 'n sinvolle nawerking in 'n opvolgende tydvak het. Dit impliseer dus dat slegs die mens geskiedenis kan hê en kan maak. 'n Natuurverskynsel is nie geskiedenis nie. Net so ook is die historiese feitelikheid van die bestaan van miljoene onbeduidende mense nie geskiedenis nie. Dit is egter geskiedenis dat 'n persoon van baie nederige stand soos Maarten Luther gebore is, geleef en gewerk het, want die feit van sy bestaan het 'n sterk nawerking in die kerk en die westerse wêreld gehad.

In teenstelling met die sikliese beskouing van die Grieke en Romeine, gee die Christendom ' $n$ liniêre geskiedsbeeld aan die wêreld (Dreyer 1974:224 v). Dit beteken dat daar 'n bepaalde beginpunt, 'n vooruitgang en 'n voleinding vir die wêreld deur God bepaal is. Binne hierdie beplanning van God is daar sin in die bestaan van die ganse mensdom.

Die liniêre geskiedsbeeld het verdere belangrike implikasies. Eerstens beteken dit dat daar nie iets is wat toevallig gebeur nie. Die gebeurtenisse in die wêreld vind plaas, omdat die mens beslissend optree om die gang van sake te bepaal. Dit is 'n opdrag wat die mens van God ontvang het om in verantwoordelikheid voor Hom op te tree. Tweedens is die dinge wat gebeur het onherhaalbaar. ' $n$ Mens mag 'n bepaalde aksie herhaal, maar die tyd waarbinne dit gedoen word, verskil en gee aan elke aksie 'n unieke omstandigheid. Derdens is dinge wat in die geskiedenis gebeur, onherroeplik. Die gevolge van 'n gebeure mag tot niet gemaak word, maar wat gebeur het, het gebeur. Vierdens het die gebeure nie net met dit te doen wat in die verlede lê nie, maar ook met die toekoms. Dit wat 'n mens vandag doen, word mede bepaal deur die toekoms waarheen jy op pad is.

"Om hierdie rede word die hede tot 'n byna skrikwekkende mate gelaai met betekenis: die hede is die punt waardeur die lyn van die verlede na die toekoms loop ..." (Dreyer 1974:225). 
'n Mens se handeling in die hede word dus deur twee oriënteringspunte bepaal, naamlik die verlede en die toekoms. Dit wat gister gebeur het, bepaal die moontlikheid van jou opdrag vandag. Die einddoel bepaal of $j y$ vandag begerig is om die werk van gister voort te sit. Die lewende mens is die eindpunt van die verlede en die beginpunt van die toekoms (Dreyer 1974:238). Dit hou in dat die mens met die oog op die verlede en die toekoms in die hede met verantwoordelikheid moet optree. Geskiedenis het dus te doen met die mens se eksistensiële plekbepaling in lewensituasies (Dreyer 1974: 238).

Hierdie genoemde beskouings raak ook die kerkgeskiedenis. Daar is egter een probleem, naamlik die feit dat die kerk onsigbaar en sigbaar is. Die onsigbare kerk onttrek hom aan wetenskaplike bestudering (Bakhuizen van den Brink 1965:1). Omdat die kerkgeskiedenis dieselfde wetenskaplike metodes gebruik as die sekulêre geskiedenis, kan die kerkgeskiedenis net die geskiedenis van die sigbare kerk bestudeer en beskryf. Daar kom egter nog 'n onvatbare grootheid in die geskiedenis van die sigbare kerk na vore. Dit is die handeling van God in die geskiedenis van die kerk (Pont 1978).

Vir die geloofsoog is die handeling van God in die kerk a posteriori sigbaar. Dit alleen ook wanneer die geskiedenis in terme van die belydenis van die kerk beskou word. Wat die wetenskaplike studie betref, is dit egter net moontlik om die optrede van die gelowige lidmaat van die Kerk te bestudeer en te beskryf. Dit impliseer egter, dat die gelowige se handelende en sprekende antwoord op die aanspraak van God in die verlede beskryf word.

Die aanspraak van God word vatbare en tasbare geskiedenis met die koms van God die Seun, Jesus Christus na die aarde toe. Vanuit die ewigheid maak God 'n vertikale insnyding in die tyd en die ruimte wat Hy geskape het. Die ewige onbegrensde God laat Hom bind deur die bande van tyd en ruimte ter wille van die mens wat in die tyd op die aarde lewe. So is Jesus Christus die middelpunt en sin van alle geskiedenis (Berkhof 1966).

Alle geskiedenis van die skepping af was bedoel as voorbereiding vir die koms van Christus in die volheid van die tyd (Pont 1978). Die wet en die profete het uitgeloop op dié punt in die geskiedenis. Die kerk leef van die hemelvaart van Christus na sy wederkoms toe. In hierdie heilsgeskiedenis gryp God in deur sy Woord en sy Gees. Die geskiedenis van die kerk is die geskiedenis van die antwoord van die gelowige deur die eeue op die aanspraak van God deur sy Woord en Gees. Dit is die geskiedenis van die deurwerking van die evangelie in die wêreld.

Die taak van die kerkgeskiedenis is dus om te beskryf hoe die Woord en Gees van God deur die eeue heen die kerk gerig en gelei het. In die uitvoering van dié taak is dit nodig dat die kerkgeskied- 
kundige sal gaan navors hoe die kerk op elke gegewe tydstip sy antwoord op God se Woord gegee het (Pont 1978). Dit impliseer dat die antwoord self weergegee moet word. Dit beteken dat die werk op die mees wetenskaplike metode wat moontlik is, gedoen moet word. Hiernaas is dit die taak van die kerkgeskiedenis om die verband te lê tussen die gebeure in die verlede en die lewende situasie van die huidige kerk. So word die kerkgeskiedenis 'n gesprek met die lidmate wat ons voorafgegaan het. So word die kerkgeskiedenis die boodskapper van die lidmate wat ons voorafgegaan het om hier in die hede te kom vertel hoe hulle as getuies van die Woord van God opgetree het (Berkelbach van der Sprenkel 1944:307). Die wat ware getuies was, roep ons op om in navolging van hulle geloof (Hebr 13:7) die waarheid van ons eie getuienis te beproef. Die wat valse getuies was, waarsku ons om ons getuienis van die waarheid te beproef. Na beide kante toe verswaar dit ons verantwoordelikheid waar ons vandag getuies van die waarheid moet wees.

In dié $\sin$ is die kerkgeskiedenis dus eerder 'n gesprek van die lidmate wat ons voorafgegaan het met ons in die hede. Hierdie gesprek word gekenmerk deur die eienskappe wat eie aan geskiedenis is.

Die verlede praat met ons, omdat daar ' $\mathrm{n}$ definitiewe band is wat ons aanmekaar bind, naamlik die Woord van God wat toentertyd en vandag dieselfde is. Hulle taak is derhalwe ons taak. Uit die kerkgeskiedenis word dit duidelik dat hulle dieselfde basiese nood, naamlik sonde en dood geken het en so ook dieselfde verwagting en hoop van verlossing gehad het. Hulle was op pad na dieselfde eschaton en telos as ons. Vanuit ons gesigspunt kan ons vandag sien dat hulle wedervaringe geensins toevallige noodlotsgrille was nie, maar dat God beskik het, sodat ons vandag in die ryke erfenis mag leef wat ons ken. Weer eens 'n verswaring van ons verantwoordelikheid om dié erfenis ongeskonde verder aan te gee aan die lidmate wat ná ons kom.

Ons sien egter ook dat hulle wedervaringe nie weer net so vandag kan plaasvind nie. Die tyd en plek verskil en alles wat daarmee saamgaan. Daarom is dit noodsaaklik om noukeurig te gaan vasstel waarom hulle sekere dinge gedoen en gesê het. Anders mag dit gebeur dat ons die verlede vir ons laat buikspreek. Hy wat na homself in die verlede luister, doen dit omdat die geklank van sy stem in die hede ook al die Woord van God verdring het. As ons egter presies weet wat in die verlede gebeur het en waarom dit gebeur het, sal dit ons ongetwyfeld oproep om noukeurig en gehoorsaam te luister na wat die Woord en Gees van God vandág vir ons wil sê. Die Woord spreek in ons situasie en ons antwoord moet vandag gegee word, anders gaan die geleentheid onherroeplik verby om ons verantwoor- 
delikheid vir vandag na te kom. Môre is nog 'n dag, maar môre is 'n ander dag.

\section{ALGEMENE KERKGESKIEDENIS AAN DIE UNIVERSITEIT VAN PRETORIA}

Sedert die totstandkoming van die Fakulteit Teologie aan die Universiteit van Pretoria is die vak Kerkgeskiedenis oftewel die Geskiedenis van die Christendom aangebied. Die vroeëre benaming van die departement te wete Geskiedenis van die Christendom dui op die noue bande wat daar indertyd met die teologiese opleiding in Nederland bestaan het. Die Hoger Onderwijswet van 1876 was in Nederland verantwoordelik vir die skeiding van die kerk en die teologiese fakulteit met betrekking tot die nie-kerklike en die niedogmatiese vakke. Onder invloed van die negentiende-eeuse wetenskaplike gees is die geskiedenis van die kerk as studieveld van die godsdiensgeskiedenis opgevat. Dit impliseer 'n breër studie as alleen die geskiedenis van die kerk van die Credo en omvat die betekenis van die Christendom op alle gebiede van die menslike lewe, dit wil sê ook daar waar die Woord nie meer geglo word nie, maar wel in die erfenis van die Christendom gedeel word. Vandaar die benaming.

Aan die Universiteit van Pretoria is egter van die begin af, ten spyte van die benaming, die geskiedenis van die kerk bestudeer en gedoseer. Die vakgebied het hoofsaaklik onder prof dr SP Engelbrecht (1921-1956) sy beslag gekry. Sy opvolger, prof dr AD Pont, dui reeds met sy akademiese intreerede op 17 Maart 1957 aan dat dit vir hom om die geskiedenis van die kerk gaan (Pont s a c:5). Sy leeropdrag is vir hom inhoudelik bepaal vanweë die kerk. As sodanig gaan dit nie om die invloed wat die Christelike geloof oral in die wêreld op die mensdom gehad het nie, maar dit gaan om die geskiedenis van die een liggaam van Christus. Dit gaan dus om die verband wat daar bestaan tussen die Nederduitsch Hervormde Kerk van Afrika van vandag (as 'n verskyningsvorm van die één heilige, algemene Christelike Kerk) met dié lidmate wat ons voorafgegaan het. Om hierdie rede het Pont hom daarvoor beywer om die naam van die Departement te verander na die Departement Kerkgeskiedenis (Pont s a b:164). Dit het hy met ingang 1973 tot stand gebring. Die naamsverandering van die departement was formeel om die naam in ooreenstemming te bring met die aard van die akademiese bedrywighede van die departement.

Uiteraard sou 'n dusdanige beskouing van die kerkgeskiedenis nie geleentheid bied om die geskiedenis van die kerk oor die hele wêreld te bestudeer nie. Alleen dié geskiedenis van die kerk waarby 'n direkte verband met die Nederduitsch Hervormde Kerk bestaan, 
word dus bestudeer. Hoe interessant en wetenswaardig die geskiedenis van die Russiese Ortodokse Kerk of die Grieks-Ortodokse Kerk ook al is, het dit nie die verbintenis met die Nederduitsch Hervormde Kerk wat dit noodsaaklik maak vir die eksistensiële plekbepaling van die Nederduitsch Hervormde Kerk nie. Daarom word slegs dié gedeeltes bestudeer wat iets te sê het vir die verstaan van ons eie plek in die kerk.

'n Volledige weergawe van die werkopdrag is sekerlik nie hier ter sake nie. Dis egter van belang om op te merk dat Kerkgeskiedenis aan die Universiteit van Pretoria Dogmengeskiedenis insluit. Wat hierdie aspek betref, word gekonsentreer op die ontwikkeling van die necessaria verae doctrinae capita, die noodsaaklike hoofstukke van die ware leer van die kerk. Dit beteken dat die weg van die kerk deur die wêreld van die begin af gevolg word totdat die kerk uiteindelik in die Nederduitsch Hervormde Kerk te voorskyn tree. Pont het aan hierdie beskouing oor en hantering van die kerkgeskiedenis grootliks beslag gegee.

So gesien, is die onderskeiding tussen Algemene Kerkgeskiedenis en Suid-Afrikaanse Kerkgeskiedenis enigsins misleidend. Afgesien van die feit dat, wat die Suid-Afrikaanse Kerkgeskiedenis betref, eintlik net die geskiedenis van die Nederduitsch Hervormde Kerk behandel word, word die Algemene Kerkgeskiedenis dus ook net behandel in soverre ook dít geskiedenis van die Nederduitsch Hervormde Kerk is, of ten minste vir die Nederduitsch Hervormde Kerk belangrik is. Tertullianus, Athanasius, Augustinus, Luther, Calvyn, Guido de Brés en Johannes Bogerman is net sulke belangrike figure uit die geskiedenis van die Nederduitsch Hervormde Kerk as di Dirk van der Hoff en MJ Goddefroy. Die belangrikheid van die eersgenoemde persone deel ons met baie ander kerkgenootskappe in die wêreld. Hulle is deel van ons almal se kerkgeskiedenis. Die laasgenoemde twee is vir ander kerkgenootskappe kerkhistoriese feite. Vir ons is hulle egter deel van ons kerkgeskiedenis. Die onderskeiding in Algemene en Suid-Afrikaanse Kerkgeskiedenis is dus slegs ' $n$ tydruimtelike onderskeiding en nie ' $n$ inhoudelike onderskeiding nie. Daarom bly dit 'n onderskeiding en geen skeiding nie.

\section{SAMEVATTENDE OPMERKINGS EN BESLUIT}

Dit lyk noodsaaklik dat na die kerkgeskiedenis as die vermanende boodskapper uit die verlede geluister moet word as ons onsself vandag reg wil oriënteer en ons verantwoordelikheid vir die toekoms wil nakom. Hierdie noodsaaklikheid word beklemtoon deur die feit dat die kerk van vandag en die kerk wat deur die geskiedenis bestudeer word, één kerk is. Die kerkgeskiedenis hou hom dus besig met die één, heilige, algemene, Christelike kerk soos wat hy deur die 
eeue heen deur die Woord en Gees van God gerig word. Solank as wat ons ons eie Suid-Afrikaanse Kerkgeskiedenis wil beoefen, solank sal ons ook noodwendig die "Algemene Kerkgeskiedenis" moet beoefen, want dis geskiedenis van dieselfde kerk. Die beoefening van die "Algemene Kerkgeskiedenis" gaan dus uit van en impliseer telkens weer opnuut die eenheid van die kerk van Christus op aarde.

Dit mag nodig word dat ons aandag aan twee kontemporêre sake sal gee. Die ekumeniese beweging kan nie as geskiedenis van die kerk in die ware sin van die woord beskou word nie. Dit is eerder'n beweging op die rand van die kerklike lewe. Nogtans sal daarvan kennis geneem moet word ter wille van ons eie oriëntering en verantwoordelikheid teenoor die res van die kerk van Christus.

Verder sal kennis geneem moet word van die geweldige sendingywer en toegespitste bearbeiding van die Rooms-Katolieke Kerk in Suid-Afrika, veral gedurende die afgelope dekade. Gepaard met die prominensie wat deur kommunikasiemedia aan die pous en die Rooms-Katolieke Kerk verleen word, vorm dit 'n nuwe, en in SuidAfrika dusver onbekende, bedreiging van ons Protestantse erfenis.

'n Waarskuwing is ook gepas. Vanweë die feit dat daar op eksegetiese gebied baie onsekerheid bestaan oor wat die Woord van God vandag vir ons te sê het, soek sommiges sekerheid en bewyse in die kerkgeskiedenis. Dit moet duidelik besef word dat geskiedsopenbaring natuurteologie is. As sodanig is dit onderworpe aan die sondeval, gevolglik verdorwe en lei op dwaalweë. Die Kerkgeskiedenis wil homself nie as openbaringsmedium van God verhef nie, maar wil oproep tot groter verantwoordelikheid by die bestudering van die Woord van God in ons dag.

\section{Literatuurverwysings}

Bakhuizen van den Brink, JN 1965. Handboek der Kerkgeskiedenis. Deel I. Den Haag. Barth, K 1947. Kirchliche Dogmatik. I Bd. I. Zürich.

Berkelbach van der Sprenkel, SFHJ 1944. Geskiedenis en heilsgeschiedenis in de kerkelijke prediking, in Bakhuizen van den Brink, JN e.a. Geskiedenis. Assen.

Berkhof, H 1966. Christus de zin der geskiedenis. Nijkerk.

Cragg, GR 1970. The church and the age of reason 1648-1789. Harmondsworth.

Dreyer, PS 1974. Inleiding tot die filosofie van die geskiedenis. Pretoria.

Emmen, E 1944. De geskiedenis-waardering der Reformatie, in Bakhuizen van den Brink, JN e.a. Geskiedenis. Assen.

Kraft, H (Hrsg.) 1967. Eusebius von Caesarea. Kirchengeschichte. Darmstadt. (H.E.).

Meinhold, P 1967. Geschichte der kirchlichen Historiographie. Freiburg/München.

Pont, AD sa a. Die geskiedenis van die Christendom. HTS 13/1.

Pont, $\mathrm{AD}$ sa a. Vyftig jaar Geskiedenis van die Christendom aan die Teologiese Fakulteit, Afdeling A van die Universiteit van Pretoria, 1917 tot 1967. HTS 22/4.

Pont, AD sa c. Kerkgeskiedenis as begrip tydens die Kerkhervorming. HTS 31/1 en 2. Pont, AD 1978. Kerkgeskiedenis (Inleiding). Pretoria.

Rasker, AJ 1974. De Nederlandse Hervormde Kerk vanaf 1795. Kampen.

Smits, EJF 1944. Die religieuze wedergeboorte van Europa in die geschiedenis-philosophie van Herder, Novalis en Görres, in Bakhuizen van den Brink, JN e.a. Geschiedenis. Assen.

Universiteit van Pretoria 1982. Jaarboek. Deel VI. 